\title{
LOGISTICAL SUPPORT OF AGRICULTURAL SECTOR IN UKRAINE: LEGAL FEATURES
}

Tetiana Kharytonova ${ }^{1}$, Illya Karakash ${ }^{2}$, Khrystyna Hryhorieva ${ }^{3}$, Lyudmila Kanivets ${ }^{4}$, Larysa Udovyka

*Corresponding authorE-mail: haritonova@onua.edu.ua

\begin{abstract}
A R T I C L E I N F O
Review Article

Received: 20 January 2020

Accepted: 30 April 2020

doi:10.5937/ekoPolj2002511K

UDC 005.5:338.431]:34(477)

Keywords:

agroindustrial complex; agricultural producers; agriculture; government support; leasing

JEL: Q10, Q14, Q15

\section{A B S T R A C T}

The article is devoted to the issue of legal regulation of logistical support of Ukrainian agriculture. The relevance of the article is that Ukraine's agriculture is far behind optimal international norms, and the provision of agriculture with fixed assets does not meet the needs of production. The authors used the dialectical method, the analysis method, the synthesis method, the logical method, the historical method, the method of comparison. As a result of the study, the following conclusions were made that the legislation on state support of agrarians in the sphere of equipment purchased is not substantiated. This is a significant destabilizing factor, as well as insufficiently professional and scientifically substantiated preparation of such regulatory acts. There is an increasing tendency for the use of a "manual regime" for providing state support in agriculture, which is in the situation of instability, is a risky way.
\end{abstract}

(C) 2020 EA. All rights reserved.

1 Tetiana Kharytonova, Doctor of Legal Science, Professor, Head of Agrarian, Land and Environmental Law Department of National University «Odesa Law Academy», Odessa, Ukraine, haritonova@onua.edu.ua, ORCID ID (https://orcid.org/0000-0002-7998-5089)

2 Illya Karakash, Doctor of Legal science, Professor of Department of Agrarian, Land and Environmental Law of National University «Odesa Law Academy», Odessa, Ukraine, ilivkar47@gmail.com, ORCID ID (https://orcid.org/0000-0003-1970-2523)

3 Khrystyna Hryhorieva, Ph. D., Associate Professor of Department of Agrarian, Land and Environmental Law of National University «Odesa Law Academy», Odessa, Ukraine, gergina8888@gmail.com, ORCID ID (https://orcid.org/0000-0001-7659-2178)

4 Lyudmila Kanivets, Ph. D., Associate Professor of Department of Agrarian, Land and Environmental Law of National University «Odesa Law Academy», Odessa, Ukraine, ludochka_k@ukr.net, ORCID ID (https://orcid.org/0000-0002-8866-4527)

5 Larysa Udovyka, Doctor of Legal science, Associate Professor of Department of History and Theory of State and Law of Zaporizhzhia National University, Zaporizhzhia, Ukraine, lora.znu@gmail.com, ORCID ID (https://orcid.org/0000-0001-9260-4474)

http://ea.bg.ac.rs 


\section{Introduction}

Logistical support is an important condition for the effective development of the Ukrainian agricultural sector. At present, Ukraine's agricultural sector is far behind the optimum standards considering this criterion, and the provision of agriculture with fixed assets does not meet the needs of production. In 2014, in agricultural enterprises, the actual availability of fixed assets per 1 hectare was only $22 \%$ lower than their regulatory demand (Zakharchuk, 2016). Despite such catastrophic consequences for agriculture caused by negligent logistical support, this problem is not even mentioned in the Law on State Aid for Agriculture in Ukraine. However, it should not be forgotten that the functioning and organization of production of agricultural products depends on the material and technical support of producers' primarily agricultural machinery, spare parts for it, fuel, and lubricants. According to V. P. Zhushman, agricultural production is dead without adequate logistical support and without the support of the state in providing agricultural producers with the means of industrial and technical purposes agriculture is unable to get out of the crisis (Zhushman, 2010).

Complex problems with the sufficiency and quality of logistical support of modern agriculture in Ukraine the urgent need to intensify the processes of state aid in this area. According to the National Joint-Stock Company "Ukragrolizing", the need for agriculture to purchase labor mechanization is UAH 15-20 billion, while the purchasing power of agricultural enterprises remains at UAH 2.5 billion. The solution is to purchase equipment under schemes that do not provide for a single transfer of the entire amount of its value at the expense of own funds. The most popular way to get money for buying expensive equipment is to enter into credit agreements with financial institutions (but their services are expensive and require some security conditions). As an alternative to the loan, agrarians were offered to use the leasing legal structure, but in times of crisis and instability, leasing services are also expensive and inaccessible. The state has offered agrarians state aid for the leasing of agricultural machinery to help solve actual problems in the field of logistical support of the agro-industrial complex. This way is aimed at eliminating the main problem - the high cost of leasing operations in commercial financial institutions.

This mechanism is that a private lessor, which requires high-interest rates, is replaced by a specialized state-owned company that sets a lower commission rate. The National Joint Stock Company "Ukragrolizing" (since 2001) and the State Enterprise "Spetsagrolizing" (since 2010) were established for this purpose. The procedure for granting state aid is regulated by this scheme by some resolutions of the Cabinet of Ministers of Ukraine (Resolution of the Cabinet of Ministers of Ukraine on the procedure of using the state budget funds for the purchase of domestic agricultural machinery and equipment for financial leasing and financial leasing operations (No. 1904/2003), 2003; Resolution of the Cabinet of Ministers of Ukraine on approval of the Procedure of using the funds provided in the state budget for financial support of agricultural entities through the mechanism of cheaper loans and compensation of leasing payments (No. 794/2010), 2010; Resolution of the Cabinet of Ministers of Ukraine on approval of the Procedure 
of using the funds provided in the state budget to increase the authorized capital of the National Joint Stock Company "Ukragrolizing" for the purchase of technical means for the agro-industrial complex with their subsequent transfer under financial leasing conditions (No. 709/2015), 2015).

Thus, legislation, implementation practices, leasing support issues under this legal mechanism require detailed investigation in this article.

\section{Materials and methods}

The authors used the dialectical method, the analysis method, the synthesis method, the logical method, the historical method, the method of comparison to write this article. The method of analysis allows to study in detail the regulatory acts supporting agricultural producers, industry. The comparison method identifies new ways to improve leasing and to abandon the inefficient method of supporting agribusiness. The dialectical method made it possible to draw conclusions from the study. The historical method helps to avoid the mistakes of the past in the effective support of the agricultural sector in the country. The materials in this scientific article were regulatory acts that provide support to the agricultural sector in the country.

\section{Results}

It should be noted that in 2014-2016, agricultural entities received indirect state aid, in particular, through a special VAT tax regime, totaling UAH 79.6 billion, fixed agricultural tax - UAH 12 billion, which is on average nearly UAH 31 billion annually.

Since 2017, Ukraine has renounced indirect state aid in agriculture, in particular through a special VAT tax regime, and has started to introduce more extensive mechanisms for direct state aid for agricultural producers. Thus, in 2014-2018 the total amount of direct state financial aid to agriculture at the expense of budgetary funds amounted to UAH 10302.7 million (actual state aid), of which 9231.3 thousand UAH in 2017-2018 (which is almost 10 times higher than the corresponding volume of 2014) (Figure 1), while in 2017-2018 almost 60\% of the total state aid was directed to support the livestock industry. 
Figure 1. Dynamics of changes in the amount of state aid for agriculture in 20142018 (UAH, thousand)

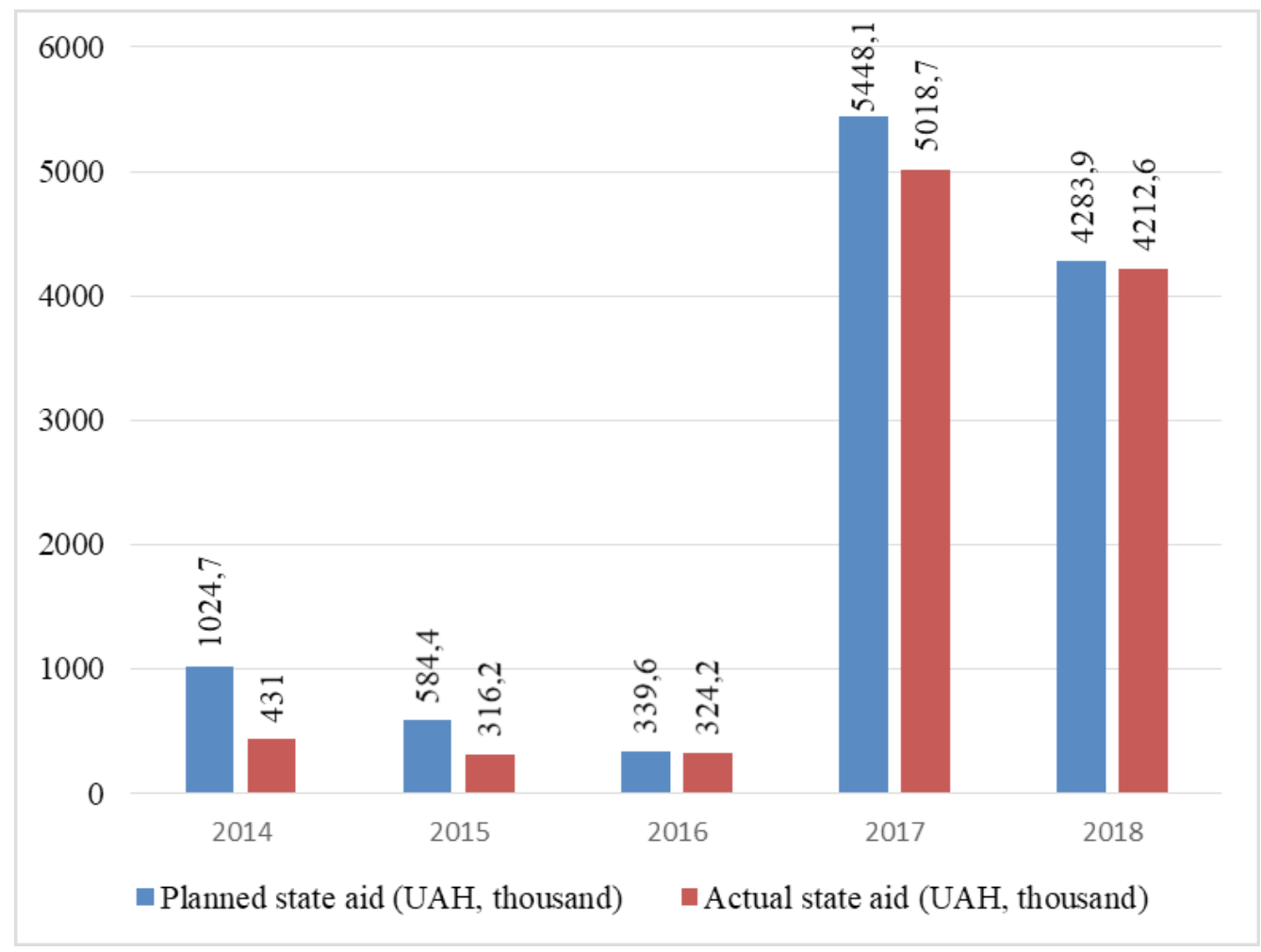

Source: Report of the Accounting Chamber on the results of the audit of the effectiveness of the use of state budget funds aimed at providing state aid to the agro-industrial complex (No. 20-6), 2019

However, both direct and indirect government subsidies are not effective. In particular, the audit conducted by the Accounting Chamber of Ukraine in 2019 of the efficiency of the use of state budget funds aimed at providing state aid to the agro-industrial complex, showed the lack of clarity of the legislatively implemented mechanisms for providing state aid to the entities receiving it, which do not fully ensure the efficient use of funds budget programs and do not contribute to the timeliness and completeness of management decisions by participants in the budget process, which affected the legality and efficiency of budget funds.

Thus, the audit revealed the fact that the state budget suffered losses in the amount of UAH 3298.1 thousand and ineffective management of funds in the amount of UAH 16821.3 thousand, which were returned to the state budget due to their non-use. In addition, the audit revealed the use in 2018 of part of the state budget funds under these programs in violation of current legislation (UAH 1,045,397.2 thousand) and not for the intended purpose (UAH 6,649.0 thousand) (Report of the Accounting Chamber on 
the results of the audit of the effectiveness of the use of state budget funds aimed at providing state aid to the agro-industrial complex (No. 20-6), 2019).

One of the effective ways of providing state aid to agricultural producers is not full financing, but point support, in particular - assistance in the purchase of agricultural machinery under leasing agreements.

Leasing in domestic agrarian legislation appeared in the context of state aid for agriculture (Presidential Decree on measures to solve the crisis of payments and support for domestic producers (No. 88/95-rp of May 22, 1995), 1995; Osadko, 2014a). At present, the legal mechanism of state aid in the field of agricultural machinery leasing is regulated by a large number of legal acts (for example, by the Decrees of the Cabinet of Ministers of Ukraine "On the Procedure of Use of State Budget Funds for the Purchase of Domestic Machinery and Equipment for Agro-Industrial Complex..., 2003; "On Approval of the Procedure of Using the Funds Provided in the State Budget for Increasing the Authorized ..., 2015; "On Approval of the Procedure of Using the Funds Provided.., 2010).

The much greater popularity of the National Joint Stock Company "Ukragrolizing" in comparison with the State Enterprise "Spetsagrolizing" stipulates that in our research it is the activity of the first state company that we focus on. The contractual nature of state aid in the field of agricultural machinery leasing imposes a significant imprint on the legal mechanism for its provision. The entities receiving such support were initially referred to in Order 2003 of 1904 as «agricultural enterprises and other business entities in the Agro-Industrial Complex», but since 2009 this list has been supplemented by Agricultural Servicing Corporations and individuals - members of private farms, which was explained by the need to consider their non-commercial status. In our view, state aid should be provided to agricultural producers and agricultural service cooperatives (as an optimal way to organize joint purchases of expensive machinery).

The object of state aid is the leasing of machinery and equipment for the agro-industrial complex, the main legal features of which are designation and origin. A technique is considered to be domestic if it combines subjective and objective criteria (Resolution of the Cabinet of Ministers of Ukraine on Approval of the Procedure for Determining the Degree of Localization of Production of Enterprises of the Machine-Building Industry for the Agro-Industrial Complex of Domestic Machinery and Equipment for the AgroIndustrial Complex (No. 369/2013), 2013). It should be noted that, although the legislation provides for the possibility to lease not only equipment but heifers and cows (Order of the Ministry of Agrarian Policy and Food of Ukraine on approval of the Regulations on the Bidding Commission on determining the priorities of providing the basic funds of agricultural producers under financial leasing (No. 504/2012), 2012; Resolution of the Cabinet of Ministers of Ukraine on approval of the Procedure of using the funds provided in the state budget for financial support of agricultural entities through the mechanism of cheaper loans and compensation of leasing payments (No. 794/2010), 2010), in fact in Ukraine this type of preferential leasing, unfortunately, does not work. 
The 2003 order did not include the criteria for the selection of lessees in its original versions, and only in 2009 a three-stage system of their definition was formed:

1) a requirement for the absence of negative conditions;

2) filtering by prevailing conditions: a) by type of activity (animal husbandry, storage); b) organizational (agricultural cooperatives, small and medium enterprises);

3) optional auctioning of bidders, which mainly secures the interests of the National Joint Stock Company "Ukragrolizing”, rather than farmers.

The contractual terms of support can be summarized in the following aspects:

a) the main contractual arrangement is financial leasing;

b) advance payment of not less than $15 \%$ of the cost of the equipment;

c) with or without transfer of the object to the lessee's property;

d) the remuneration of the National Joint Stock Company "Ukragrolizing" has not been fixed at a solid percentage (since 2015 it amounted to 50\% of the National Bank of Ukraine discount rate per annum of undamaged equipment cost);

e) the medium-term effect of the contract (in science it is necessary to extend the lease term for a long-term term (Osadko, 2014b).

The characteristics of the main elements of the legal mechanism of preferential leasing should be complemented by research into the practice of implementing such support. The analysis of court case files allows all disputes to be presented in the form of three main groups of violations:

1) the breach of the schedule of payment of lease payments (for example, The decision of the Commercial Court of Kyiv of September, 5, 2016);

2) the violation of the requirements for insurance of the leased asset (for example, The decision of the Commercial Court of the Kyiv region of September, 10, 2015; The decision of the Rivne Economic Court of Appeal of January 1, 2015);

3 ) the violation of the operating conditions of the equipment, resulting in a decrease in its cost compared to the calculated one (for example, The decision of the Commercial Court of Kyiv of December 3, 2013).

Leasing is described and analyzed in the literature (Yermolenko, 2010; Barabash, 2004; Berlach, 2009; Kornienko, 2005; Osadko, 2016; Semchik, 2001; Stativka, 1999; Stoyko, 2014), but its popularity in the agro-industrial complex remains unsatisfactory, especially in the face of an acute shortage of logistical support in domestic agriculture. The National Joint Stock Company "Ukragrolizing" has a powerful protection potential that is underutilized. It is quite eloquent to recognize the fact that the company is lagging behind its competitors in the leasing market (Decision of the directorate of NJSC "Ukragrolizing" on approval of the terms of transfer of equipment for financial 
leasing by the National Joint Stock Company "Ukragrolizing" (dated February 28, 2019), 2019). As a result of the analysis of the legal mechanism of state aid in the field of leasing, as well as the study of the case law, we have come to the conclusion that protectionism should become the main purpose of activity of the National Joint Stock Company "Ukragrolizing" in comparison with the purpose of profit (Grigorieva, 2017).

From this point of view, the protection character should be realized in the following components:

a) the attractiveness of the offer - this means that the priority of the activity should be the expansion of the range of equipment based on constant monitoring of consumer demand;

b) cheapness and profitability - this means setting the minimum required a percentage of remuneration aimed at ensuring optimized activity of the National Joint Stock Company "Ukragrolizing". Many scientists point to a significant unjustified increase in the price of the equipment as a result of the operation of the National Joint Stock Company "Ukragrolizing" (Svistun, 2009; Golovchuk, \& Nepochenko, 2010), and this fact significantly reduces the agro-protective effect of state support;

c) affordability - this means the simplest possible procedure for participation in the preferential leasing program. Currently, the batch of documents required for the initial submission is about 16 different documents (National Joint Stock Company "Ukragrolizing", 2019). Nevertheless, the appeal is not guaranteed to be satisfied. Given the contractual nature of this type of state support, in our view, it is quite possible to limit ourselves to general documents of the person and documents confirming the absence of negative conditions and the presence of prevailing ones. It would be convenient to develop an automated electronic filing system and a package of documents for the initial review. Such a step would allow, among other things, to optimize the structure of the National Joint Stock Company "Ukragrolizing" and its activities;

d) flexibility - this means applying an individual approach, categorizing clients (Dudchik, 2019), reaching compromise decisions on reviewing payment schedules for leasing payments, etc. In this case, flexibility should not turn into permissiveness. A weak system of liability for breach of the lease agreement resulted in mass ignoring of schedules and considerable losses of the state in similar legal relations in Belarus (Drozdov, 2008). A. S. Osadko (2016) points out that most of the problems that accompany state aid in the field of agricultural machinery leasing lie in the legal position of the national jointstock company "Ukragrolizing" or the improper exercise of its rights and obligations. The analysis of the legal mechanism of direct preferential leasing of agricultural machinery and equipment indicates the need to improve the legislative regulation of these relations. 
Unlike the previous legal mechanism for leasing agricultural machinery, the legal mechanism for compensation for leasing payments has a legal basis at the level of the Law of Ukraine "On State Support for Agriculture of Ukraine", although they have emerged only since 2012 (Law on Amendments to Article 13 of the Law of Ukraine on State Aid of Agriculture of Ukraine (Verdicts of the Verkhovna Rada of Ukraine, No. 31/2012, p. 383, 2011). The objects of state support are leasing payments under a financial lease contract concluded by an agrarian with a financial institution. The entity's expenses to be recovered are of two types: a lease payment ( $40 \%$ of the leased asset's value) and a lessor's fee (1.5\% National Bank of Ukraine discount rates) (Resolution of the Cabinet of Ministers of Ukraine on Approval of the Procedure of Using the Funds Provided in the State Budget for Financial Support of Measures in the Agro-Industrial Complex on Conditions of Financial Leasing (No. 648/2010), 2010). The legal basis for such support has not developed, and the main reason is the lack of financing of the budget program in the direction of compensation for leasing payments, and therefore, the lack of need to adjust the legal framework for its implementation.

\section{Discussions}

As a result of the study of the features of legal mechanisms of state aid in the field of leasing of agricultural machinery in Ukraine, we can draw some conclusions. The proposed method of state aid - the provision of equipment for preferential leasing is contractual in nature and the legal relationships that are formed in the process of providing it have the features of traditional financial leasing.

The main differences of the analyzed legal mechanisms can be represented as follows:

1) the preferential lease agreement is beneficial to the state, the agrarian and the supplier, whereas the compensation of leasing payments is directed only to the agrarian;

2) the state can profit from preferential contracts - there is no such opportunity when compensating for leasing payments;

3) state regulation of concluding of the preferential lease agreement is supplemented, if necessary, by contractual regulation. The regulation of the procedure for compensation of leasing payments is characterized by gaps in the legislation;

4) when concluding a preferential contract, a certain degree of freedom of action remains, whereas state aid in the form of payment compensation is enclosed within the rigid frameworks of the agrarian-legal procedure, and the recipient has no possibility to influence the conditions of granting him support.

\section{Conclusions}

As a result of the conducted research, we can conclude that the legislation on state aid of agrarians in the sphere of equipment purchased is not substantiated. The legal 
acts governing these relationships are subject to permanent amendment, which is often fundamental and corrects essential aspects of state aid directly in the process of providing it. This is a significant destabilizing factor, as well as insufficiently professional and scientifically substantiated preparation of such regulatory acts. Also, the example of the analyzed program of compensation for the cost of technology can see the ambiguity of measures aimed at such a fight against bureaucracy. The removal of such barriers by involving banks instead of government bodies was eliminated by the lengthy procedure of harmonization of equipment lists. On the one hand, funding for state support is increasing, and on the other, farmers cannot obtain it because of the imperfection of the organizational and legal framework. It can be concluded that there is an increasing tendency for the use of a "manual regime" for providing state aid in agriculture, which is a situation of instability is a rather risky method. These conclusions should be taken into account in further improving the legislative regulation of government leasing support. In our opinion, relations of state aid in the field of agroleasing should find their legislative regulation at the level of the laws of Ukraine «On state aid of agriculture of Ukraine" and "On state logistical aid of agriculture».

\section{Conflict of interests}

The authors declare no conflict of interest.

\section{References}

1. Barabash, A. G. (2004). Legal regulation of leasing relations in Ukraine. Donetsk: Institute of Economic and Legal Research of the National Academy of Sciences of Ukraine.

2. Berlach, N. (2009). Ways to improve public policy in the leasing relations of agroindustrial complex of Ukraine. Entrepreneurship, Economics, Law, 10, 219 221.

3. Decision of the directorate of NJSC "Ukragrolizing" on approval of the terms of transfer of equipment for financial leasing by the National Joint Stock Company "Ukragrolizing” (dated February 28, 2019). (2019). National Joint Stock Company "Ukragrolizing". Retrieved from http://www.ukragroleasing.com.ua/index.php?/ umovi-nadannya-tehniki-u-finansoviy-lizing.html.

4. Drozdov, P. A. (2008). State agroleasing. Problems and solutions. Belarusian Agriculture, 12 (80), 22-25.

5. Dudchik, O. Y. (2019). Optimization of state leasing in the agrarian sector of Ukraine. Scientific Word. Retrieved from www.sworld.com.ua/konfer27/495.pdf.

6. Golovchuk, A.F., \& Nepochenko, O.O. (2010). Agro leasing as a mechanism for realization of the state investment policy. Proceedings of the Uman National University of Horticulture, 74 (2), $7-16$.

7. Grigorieva, H.A. (2017). Legal support for state support in the field of leasing of agricultural machinery and equipment in Ukraine. Law and Society, 1, $92-98$. 
8. Kornienko, G.S. (2005). Legal regulation of logistical support of agricultural producers in the conditions of reforming agroindustrial complex. Kharkiv: Law.

9. Law on Amendments to Article 13 of the Law of Ukraine on State Aid of Agriculture of Ukraine (Verdicts of the Verkhovna Rada of Ukraine, No. 31/2012, p. 383). (2012). Retrieved from https://zakon.rada.gov.ua/laws/show/4216-17.

10. National Joint Stock Company "Ukragrolizing". (2019). Retrieved from http:// www.ukragroleasing.com.ua.

11. Order of the Ministry of Agrarian Policy and Food of Ukraine on approval of the Regulations on the Bidding Commission on determining the priorities of providing the basic funds of agricultural producers under financial leasing (No. 504/2012). (2012). Retrieved from https://zakon.rada.gov.ua/laws/show/z1496-12.

12. Osadko,A. S. (2014a). The legal nature of the lease agreement for agricultural machinery. Development of legal forms of management in the agrarian sector. Kharkiv: Law.

13. Osadko, A. S. (2014b). The role of the leasing contract in the agriculture of Ukraine. Scientific Bulletin of National University of Life and Environmental Sciences of Ukraine, 197 (2), 91-95.

14. Osadko, A. S. (2016). Legal regulation of leasing relations with the participation of agricultural producers. Kharkiv: Law.

15. Presidential Decree on measures to solve the crisis of payments and support for domestic producers (No. 88/95-rp of May 22, 1995). (1995). Retrieved from https:// zakon.rada.gov.ua/rada/show/88/95-\%D1\%80\%D0\%BF

16. Report of the Accounting Chamber on the results of the audit of the effectiveness of the use of state budget funds aimed at providing state aid to the agro-industrial complex (No. 20-6). (2019). Retrieved from https://rp.gov.ua/upload-files/Activity/ Collegium/2019/20-6_2019/Zvit_20-6_2019.pdf

17. Resolution of the Cabinet of Ministers of Ukraine on Approval of the Procedure for Determining the Degree of Localization of Production of Enterprises of the Machine-Building Industry for the Agro-Industrial Complex of Domestic Machinery and Equipment for the Agro-Industrial Complex (No. 369/2013). (2013). Retrieved from https://zakon.rada.gov.ua/laws/show/369-2013-\%D0\%BF?lang=ru.

18. Resolution of the Cabinet of Ministers of Ukraine on Approval of the Procedure of Using the Funds Provided in the State Budget for Financial Support of Measures in the Agro-Industrial Complex on Conditions of Financial Leasing (No. 648/2010). (2010). Retrieved from https://zakon.rada.gov.ua/laws/show/648-2010-\%D0\%BF.

19. Resolution of the Cabinet of Ministers of Ukraine on approval of the Procedure of using the funds provided in the state budget to increase the authorized capital of the National Joint Stock Company "Ukragrolizing" for the purchase of technical means for the agro-industrial complex with their subsequent transfer under financial leasing conditions (No. 709/2015). (2015). Retrieved from https://zakon.rada.gov. ua/rada/show/709-2015-\%D0\%BF. 
20. Resolution of the Cabinet of Ministers of Ukraine on approval of the Procedure of using the funds provided in the state budget for financial support of agricultural entities through the mechanism of cheaper loans and compensation of leasing payments (No. 794/2010). (2010). Retrieved from https://zakon.rada.gov.ua/laws/ show $/ 794-2010-\%$ D0\%BF.

21. Resolution of the Cabinet of Ministers of Ukraine on the procedure of using the state budget funds for the purchase of domestic agricultural machinery and equipment for financial leasing and financial leasing operations (No. 1904/2003). (2003). Retrieved from https://zakon.rada.gov.ua/laws/show/1904-2003-\%D0\%BF.

22. Semchik, V. I. (Ed). (2001). Problems of ownership and management in agriculture. Kyiv: Institute of State and Law of the National Academy of Sciences of Ukraine.

23. Stativka, A. N. (1999). New types of contractual relations with the participation of agricultural producers. Kharkiv: Law.

24. Stoyko, O. E. (2014). Status and prospects of leasing in the agricultural sector of Ukraine. Productivity of agro-industrial production, 26, $19-26$.

25. Svistun, M. (2009). State regulation of ensuring the resource security of agriculture of Ukraine. Bulletin of the Lviv University, 42, 185 - 190.

26. The decision of the Commercial Court of Kyiv of December 3, 2013 in case No. 906/1245/13. Register of court decisions. Retrieved from http://reyestr.court.gov. ua/Review/35867197.

27. The decision of the Commercial Court of Kyiv of September, 5, 2016 in case No. 910/6776/16. (2016). Register of court decisions. Retrieved from http://reyestr. court.gov.ua/Review/61137437.

28. The decision of the Commercial Court of the Kyiv region of September, 10, 2015 in case No. 911/3075/15. (2015). Register of court decisions. Retrieved from http:// reyestr.court.gov.ua/Review/51827558.

29. The decision of the Rivne Economic Court of Appeal of January 1, 2015 in case No. 924/1300/14. (2014). Register of court decisions. Retrieved from http://reyestr. court.gov.ua/Review/42496398.

30. Yermolenko, V.M. (Ed). (2010). Agrarian law of Ukraine. Kyiv: Yurincom Inter.

31. Zakharchuk, O. V. (2016). Logistical support of agricultural enterprises of Ukraine and their modernization. Economics of Agro-Industrial Complex, 7, 72-79.

32. Zhushman, V.P. (2010). Support for the domestic agricultural producer is the most important direction of overcoming the economic and social crisis: legal aspects. Problems of Legality, 108, 107-114. 